University of Maryland Francis King Carey School of Law

DigitalCommons@UM Carey Law

$1-1-1998$

\title{
Toward a Framework of Mutualism: The Jewish Community in Genetics Research
}

Karen H. Rothenberg

University of Maryland School of Law, krothenberg@law.umaryland.edu

Amy B. Rutkin

Follow this and additional works at: https://digitalcommons.law.umaryland.edu/fac_pubs

Part of the Genetics Commons, and the Health Law and Policy Commons

\section{Digital Commons Citation}

Rothenberg, Karen H. and Rutkin, Amy B., "Toward a Framework of Mutualism: The Jewish Community in Genetics Research" (1998). Faculty Scholarship. 163.

https://digitalcommons.law.umaryland.edu/fac_pubs/163

This Article is brought to you for free and open access by the Francis King Carey School of Law Faculty at DigitalCommons@UM Carey Law. It has been accepted for inclusion in Faculty Scholarship by an authorized administrator of DigitalCommons@UM Carey Law. For more information, please contact smccarty@law.umaryland.edu. 
Toward a Framework of Mutualism: The Jewish Community in Genetics Research

Karen H. Rothenberg; Amy B. Rutkin

Community Genetics; 1998; 1, 3; Health Module

pg. 148

NOTICE: this material may be protected

by copyright law (Titio 17 U.S. Code)

\section{Community}

\author{
Woren HI Rothenbers:

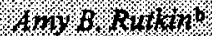 \\ - University of Maryland School of Law, \\ Baltimore, Md., and \\ - Hadassah, New York, N.Y., USA
}

\section{Toward a Framework of Mutualism: The Jewish Community in Genetics Research}

\section{Koy Words}

Genetics research

Jewish

Stigmatization

Genetic discrimination

Tissue samples

Research ethics

\begin{abstract}
The ability of scientists to identify genes believed to cause inherited diseases, including familial cancers, has become considerably refined over the last two decades because of technological breakthroughs. When research published in 1995 appeared to show that genetic mutations linked to breast and ovarian cancers (BRCA1 and BRCA2) occur more frequently in Jews of Eastern European descent than in the general population, the first response among Jewish women was to rush to participate in research. When a gene linked to colorectal cancer was identified in $6 \%$ of the Jewish population in 1997, however, press reports began to carry inaccurate and inflammatory headlines about Jewish 'mutant gene carriers', raising fears of discrimination and loss of privacy. Some rabbis and other leaders of the Jewish community began to quietly advise Jews not to get a genetic test or participate in genetics research until legal protections against discrimination are established. At the present time, a subtle tension is developing between the Jewish tradition of encouraging the acquisition of knowledge, particularly medical knowledge (exemplified by the community's successful collaboration with genetic researchers when tests for Tay-Sachs disease were developed in the 1970s) and the fear of potential discrimination or stigmatization. In order to address this tension, and ensure the continued participation by the Jewish community in critical genetics research, a framework based on the mutual interests of researchers and participants should be formulated. Such a framework of dialogue and policy would be useful in building an important element of trust for the Jewish community and other distinct communities who are sought for such research.
\end{abstract}

No social group is better equipped either in its ability to provide reliable, ordered health data or in its capacity to interpret its genetic and medical implications than the Jewish community. At the same time, no group has greater reason to be wary of the way in which such implications can be misused [1].

\begin{tabular}{|c|c|}
\hline KARGER & $\begin{array}{l}\text { 1999 S. Karser AG, Besel } \\
\text { 1422-2799/98/0013-0148S 17.50/0 }\end{array}$ \\
\hline $\begin{array}{l}\text { Fax }+41613061234 \\
\text { E-Mril kangerelarter.ch } \\
\text { www. kanper.corn }\end{array}$ & $\begin{array}{l}\text { Accestible online at: } \\
\text { hutp:/BioMedNetoon / }\end{array}$ \\
\hline
\end{tabular}

The explosion of knowledge in the science of genetics over the decade has profoundly affected the ability to diagnose inherited disease and encouraged bold theories of genetic therapy. Since 1990, the United States government has firmly endorsed the international 15-year effort known as the Human Genome Project in its intent to map

Reproduced with permission of the copyright owner. Further reproduction prohibited without permission. 
and sequence all of the human genes. (The Human Genome Project is under the auspices of the Department of Energy's Human Genome Program and the National Institutes of Health's National Human Genome Research Institute). This ambitious effort will further expand scientific understanding as well as the possibility of identifying genetic mutations and implementing medical intervention on a germline level [2]. Once the province of specialty journals, reports on new findings in genetics have filtered down to the popular press and headlines announcing that 'the' gene for some condition or other has been "discovered' are weekly occurrences.

This was the case in 1995, when genetic mutations associated with some forms of breast and ovarian cancer, BRCA1 and BRCA2, were identified by researchers. The studies suggested that these genetic alterations occurred with higher frequency in Jewish women of Eastern European ancestry (Ashkenazi Jews) than in those of other ethnic groups $[3,4]$. Widely covered by the media, these findings which linked an individual's genetic make-up, propensity for disease, and ethnic heritage set off a chain reaction within the organized Jewish community because of both the benefits and the possible consequences created by such discoveries.

When the news that the mutations had been identified appeared in the popular press, the reaction of the organized Jewish community was predictable: to a people for whom learning is an article of faith, knowledge means power. Although there was certainly a component of fear regarding the news of an intensified vulnerability to cancer, many Jewish women with family histories of breast or ovarian cancer wanted to know if they carried these genetic mutations - they wanted to have access to a genetic test. The discovery of the mutation implied only that Ashkenazi Jewish women had a distinct and potentially heightened hereditary susceptibility to certain forms of breast and ovarian cancers. For example, it is estimated that no more than $10 \%$ of breast cancer is caused by hereditary genetic mutations [5]. Even though these women understood that such a test could not possibly be $100 \%$ predictive of the onset of breast or ovarian cancer, they just wanted to have as much information as they could get their hands on. Some Jewish community leaders and researchers even discussed the possibility of population-based screening $[6,7]$.

Jewish women throughout the country also wanted to help researchers better understand this issue. By early 1996, for example, over 5,000 Ashkenazi Jewish women and men had volunteered to participate in an NIH-sponsored project in the metropolitan Washington, D.C. area
[8]. NIH researchers, in fact, did seek the active endorsement and assistance from Jewish community organizations and leadership to actively promote participation in the study.

This active enthusiasm was not uniform throughout the United States. Concerned breast cancer advocates and some Jewish leaders in the Boston community were actually dissuading Jewish women from getting a genetic test or participating in a genetics research study sponsored by the Dana Farber Cancer Institute. The researchers had asked the Jewish leaders if they would be interested in helping involve the local community in further cancer genetics research and proposed a theoretical study. Those leaders expressed concern about the lack of adequate public policy protections against genetic discrimination, and politely declined on behalf of the community $[9,10]$.

Then in 1997, when members of a research team at Johns Hopkins found a genetic mutation for colorectal cancer that they predicted was present in $6 \%$ of the Jewish community, a new anxiety arose. Hadassah, the country's largest Jewish women's organization with a history for advocating for women's bealth issues, began getting phone calls from concerned members of the Jewish community. The questions ranged from: 'Do Jews really have more genetic mutations than other people? to 'Why are Jews being studied so extensively?' Other leaders of Jewish organizations also began to acknowledge the deepening community concerns [11-13].

Rabbi Moshe Tendler, a renowned medical ethicist at Yeshiva University and a highly influential and visible Orthodox leader, was then described in The New York Times as saying that he would discourage Jews from participating in research until protections are passed. Rabbi Tendler stated: 'There's so much promise that I always walk gingerly when it means holding back any aspect of research. Yet, you have to weigh the risks against the benefits' [10].

This concern regarding discrimination in obtaining insurance or in the job market is a powerful disincentive for participation in testing programs and research. In addition to anecdotal reports of discrimination, two academic studies also claim to have documented genetic discrimination $[14,15]$. Fears of such discrimination have led some individuals to avoid testing even where it might have been medically useful [16]. In early May 1998, Associated Press cited an NIH study in which $32 \%$ of women who were asked to participate in breast cancer genetic mutations research actually declined. Most of these women cited fear of discrimination and a loss of privacy as their reasons for not participating in the research [17]. 
Both the Jewish community and the genetics research establishment have been critical voices calling for the passage of federal genetic nondiscrimination legislation.

The community leaders, as well as the individual women who called Hadassah, feared genetic discrimination on a number of levels. If women either got a genetic test or participated in a research study, there was no sure way to protect them against insurance or employment discrimination based on genetic information. They voiced concern that Ashkenazi Jewish women could become part of an 'insurance underclass', unable to obtain or afford proper health insurance. The Jewish community had learned of the well-documented experiences of discrimination with respect to sickle cell anemia and other genetically linked diseases [18].

If individual members of the Jewish community were feeling vulnerable to potential discrimination as an unintended result of the fast-breaking genetics research, misleading media headlines and sound bites began to illuminate the potential for group stigmatization as well. Headlines appeared in the Jewish and secular popular press announcing sentiments like 'Breast Cancer Strikes Jewish Women More Often Than Others' (which is patently false) and 'Ashkenazi Jews Weather News of Another Gene Flaw'. One magazine even went so far as to headline the 'Jewish gene' for breast and ovarian cancer, when referring to the BRCA1 mutation on its front cover [1921]. Immediately following the colorectal cancer announcement, a newspaper's headline attached to an opinion article written by Hadassah to promote genetic antidiscrimination legislation read, 'Protect Insurance for Mutant Gene Carriers [22]'. Such inflammatory language and reporting, both in the Jewish and secular press, contributed to growing wariness and fears. In fact, it was reported that in a study of 20 Jewish families, opinions about breast cancer research varied: half supported it while the other half felt victimized by it [10].

Signs of the potential for group stigmatization also appeared on the Internet. An ominous example is found in a legislative 'Action Alert' and article published by B'nai B'rith, a large Jewish organization. As originally written, the alert and article mentioned the genetic predisposition to breast cancer among Ashkenazi Jewish women and spoke of increased funding for breast cancer research. It called for passage of genetic nondiscrimination legislation. However, once it was posted on the Internet, it was hijacked by a 'white power' group and altered to read, 'Jews get a special type of breast cancer caused by geneticsl' [23]. Needless to say, anti-Semites believed they had 'substantiation' for their racist views about the 'genetic inferiority' of Jews long before the onset of modern genetic research. The findings simply provided additional buttressing for their argumentation that Jews are a racial group, and so necessarily have 'intelligence, behavioral and other differences built into their biology' [24].

The mere hint of notions of genetic inferiority raises historical sensitivity in the Jewish community. During the early 1900 s, eugenicists played an influential role in the enactment of US laws restricting immigration of those feit to be genetically undesirable, especially Russian and Polish Jews and Southern Italians [25]. It goes without saying that the mention of 'Jewish genes' is chilling for many Jews, calling to mind the horrors of the Nazis' efforts to justify their 'Final Solution' as a remedy for the problem of Jews polluting the world with their 'inferior' genes.

These concerns are at odds with the fact that the Jewish population generally recognizes the value of genetic research. They see not only a potential medical benefit to their people, but also a way to contribute to society as a whole. This strong belief in social justice is a fundamental Jewish value. In urging Jews to participate in the 1996 NIH study on BRCA1, Rabbi Matthew Simon, the president of the United Jewish Appeal Federation of Greater Washington said: 'In history, Jews have bled for negative reasons', and characterized this study as an opportunity for Jews to give blood to help their people [26]. Citing the important health benefits that could be realized from such research, Dr. Kenneth Offit, a cancer genetics expert said: 'I try telling people in the Jewish community that this gene research shouldn't be viewed as a stigma but as a real opportunity to provide a major breakthrough in understanding cancer' [27].

As an answer to the concern that Jews are 'targeted' by researchers, there clearly are sound scientific and other reasons why the Jewish community is studied often and early including:

- the so-called 'founder effect' - when a population group is descended from a small handful of ancestors, and historically shuns intermarriage or is forcibly ghettoized, genetic lineages (including disease-causing $\mathrm{mu}$ tations) are maintained [28];

- the theory of 'genetic drift' or 'bottleneck' which occurs when a genetic mutation becomes common because the population in which it is found dwindles due to famine, war, epidemic, or other event, as happened to the Eastern European Jewish population in the 15th and 16 th centuries [29], and

- the willingness of the Jewish community to participate in medical studies as part of our religious mandate to do 'social justice' work [10]. 
Although some of these factors might lead to the belief that Eastern European Jews are more likely than other groups to have genetic mutations, as Dr. Francis Collins of the National Human Genome Research Institute has said repeatedly, everyone - regardless of race, ethnicity or gender - has a handful of genetic mutations that confer some kind of negative trait or disease. As one researcher put it: 'Ashkenazi Jews aren't victims of their genes. It's just that we've learned about them first [30]'. Continuing to use the Jewish community as a starting point, researchers are carrying on their work to discover genetic links to diseases and traits on every piece of human DNA. Unfortunately, the evolving nature of genetic discovery runs the risk of labelling Jews as possessing greater 'propensity' for genetic disease than members of other groups, and therefore may confer upon them early social harm.

The Jewish community has considerable past history with addressing genetic disease. More than 30 years ago, Tay-Sachs, a devastating disorder causing progressive deterioration and death in very young children, was identified as an autosomal recessive trait common to members of the Ashkenazi Jewish community. Identification of this mutation led to a voluntary program, sponsored and publicized by Jewish community organizations across the nation, for the testing of couples before pregnancy. As a result of this screening program and the integration of Tay-Sachs testing into prenatal care for Jewish women, there was a $90 \%$ reduction in the incidence of Tay-Sachs in the Jewish populations of the United States and Canada from the period from 1970-1993 [31]. The Jewish community considers this success story an important legacy.

Genetics research on predisposition to disease raises different challenges and a new paradigm from the TaySachs experience. The Tay-Sachs scenario was compelling because identification of the mutation gave the carriers, if not a cure, at least options and choices regarding producing a child with this totally disabling and fatal syndrome. That is not the case with BRCA1 and BRCA2. Tay-Sachs can be diagnosed prenatally and manifests itself very early in life. The subjects of the current breast and ovarian cancer research have adult onset. Tay-Sachs is a recessive disorder which means the child who inherits a gene from each parent will definitely develop the disease, with its progressive deterioration until death within the first 5 years of life. However, if an individual is found to have a genetic mutation associated with cancer, for example, it is not known whether that individual will ever develop cancer and what the prognosis will be. If both prospective parents carry the Tay-Sachs trait or a fetus tests positive

The Jewish Community in Genetics Research for Tay-Sachs, there are choices regarding marriage, childbearing or termination. If individuals are told that they carry a defective gene that might make them more likely to develop cancer, they are faced with great uncertainty about the meaning of both the information and their alternatives. Predisposition to disease is not a diagnosis.

There is another legacy to the successful experience with Tay-Sachs testing. Although Jews may not have more genetic mutations than other groups of people, they may be easier to study because a large collection of Tay-Sachs samples have been archived since the 1970 s for future use. This readily available supply of tissue samples, identified by ethnic group (Ashkenazi Jews), is considered by researchers to be both convenient and efficient [32].

When it was reported that one of the colorectal cancer researchers relied on hundreds of samples from anonymous Jews who had been screened during the mass TaySachs testing of the early 1970 s, without Institutional Review Board approval, some Jewish community members admitted real concern $[33,34]$. They learned that there exist no uniform guidelines that require Institutional Review Board approval for the use of anonymized stored tissue samples in research. Moreover, no regulations require any consultation with the group or community to be studied, when the stored tissue samples sought, though anonymized for individual identification, may be linked back to an identified group.

How then can our approach to regulation of research risk adequately address these growing concerns raised by genetics research? Should we infer, for example, that all individuals who consented to Tay-Sachs testing in a clinical context many years ago would have agreed to provide their tissue for whatever study a researcher may propose to conduct today? Perhaps individuals would be comfortable with the use of their tissue for cancer research, but uncomfortable with its use for support of behavioral Benetic studies. Obviously, it is not possible to obtain consent from all of these individuals. But should there be no process in which the relative risks and benefits of a genetics research study on an ethnic group be evaluated before it proceeds using its stored tissue samples? Should there be a formal role for the community to advise or consult on future genetics of stored tissue samples? How might we define the community or its interests? At what point is it appropriate to share a proposed research protocol with the community? How might the informed consent process address these concerns for identifying group risks?

These questions are not unique to the Jewish community but are also of concern to other communities. In fact, the National Bicethics Advisory Commission is currently 
addressing these issues in the context of examining the use of archived tissue samples and informed consent in genetic research [35]. In addition, scientific journals are beginning to address the broader topic of 'group rights' in genetics research involving human subjects [36-38].

Many of these issues pose considerable challenges both to the Jewish community and the research establishment. In April 1998, Hadassah, the Jewish Council for Public Affairs, and the National Human Genome Research Institute convened a meeting in Washington which brought together the top rabbis and leaders from nearly every religious movement and significant organization in the Jewish community. The goal of the meeting was to "ensure the continued participation by the Ashkenazi Jewish community in critical genetics research within a framework where risks to the community are considered and minimized' [39]. At the meeting, researchers and Jewish leaders made a commitment to join together to heighten lobbying efforts for genetic nondiscrimination legislation, to create a 'standard lexicon' of nonstigmatizing language to be used in the reporting of research findings, and to continue a dialogue. In a statement released by the American Jewish Congress and several noted genetics re- searchers, they urged that 'Genetics researchers and members of the Jewish community should maintain an ongoing dialogue so that each may be apprised of the other's concerns about genetics research involving Jews' [40],

Indeed, this meeting represented an important first step in the recognition of mutual interests and in the building of an important element of trust. That sense of trust, based on the notion that community concems and needs are being heard within the context of specific research goals, will go far in helping to move the genetics research agenda forward. If we are to reach the promise of the Human Genome Project to alleviate much human suffering in all communities, we must continue to work together in partnership toward a framework of mutualism that includes policy and dialogue. Without trust and mutual respect, the very future of genetics research is at risk.

\section{Acknowledgments}

Our gratitude to Judith Horowitz Richter, JD, for her outstanding editorial assistance.

\section{References}

1 Ashkenazi signals are timely (editorial). Nature 1997;389:315.

2 Andrews LB, Fullarton JE, Hoitzman NA, MO tulsky AG (eds): Assessing Genetic Risks: Im. plications for Health and Social Policy. New York, National Academy Press, 1994.

3 Struewing JP, Albeliovich D, Peretz T, Aviaha N, Kaback MM, Collins FS, et al: The carrier frequency of the BRCAl 185 delAG mutation is approximately 1 percent in Ashkennzi Jewrish individuals. Nat Genet 1995;11:198-200.

4 Neuhusen S, Gilewski T, Norton L, Tran T, MeGuire P, Swensen J, et al: Recurren BRCA2 6174delT mutations in Ashkenszi Je wish women affected by breast cancer. Nat Genet 1996;13:126-128.

5 Kahn P: Coming to grips with genes and risk. Science 1996;274;496-498.

6 Harris L: Doctor's panel addrewes Ashkenzzic cancer concerns. Northern Calif Jewish Bul May 3, 1996.

7 Ochs R: Genetic findings on breast cancer. The door's open, researchers say, but the landacape remains murky. Newsday, May 14, 1996, Sect B, p 23.

8 Rotheaberg KH: Breast cancer, the genotic 'quick fix', and the Jewish community. Health Matrix 1997;7:97-124.
9 Saltus R: Jewinh women's group warns of risks of cancer-gene festing. Boston Globe, Jan 17, 1997, Sect B, p 2.

10 Stolberg SG: Concern among Jews is heightened as scientists deepen gene studies. New York Times, Apr 22, 1998, Sect A, p 24, col. 1

11 Weis R: Discovery of 'Jewish' cancer gene raises fears of more than disease. Washington Poet, Sept 3, 1997, Soct A, p3.

12 Wade N: Ideas \& trends: Teating genes to anve a life without costing you a job. New York Times, Sept 14, 1997, Sect A, p 5, col 3.

13 Coben DN: Colon cancer gene discovery prompts fear. Jewish Newa N J, Mar 20, 1998.

14 Laphum EV, Kozma C, Weiss JO: Genetic discrimination: Perspectives of consumers. Science 1996;274:621-624.

15 Geller LN, Aper JS, Billings PR, Barash Cl, Bockwith J, Natowicz MR: Individual, family, and societal dimensions of genetic discrimination: A case study andyais. Sci Eng Ethics 1996;2:71-88.

16 Kolata G: Genctic testing falls short of public embrace. New York Times, Mar 27, 1998, Sect A, p 16, col. 1 .
17 Hendren J: Stalled laws cause fear over lose of medical insurance. Associated Press, April 12, 1998

18 Reilly PR: Genetics, Law and Social Policy Bocton, Harvard University Press, 1977, pp 62-86.

19 Cohen DN: Breast cancer strikes Jewish women more often than others. Kansas City Jewish Chronick, Oct 6, 1995.

20 Bor J: Ashkengzi Jews weat her news of another gene flaw. Baltimore Sum, Sept 1,1997 ; Sect B, pl.

21 Wadler J: Cancer redux: '... We didn't know then about the 'Jewish gene' and ovarian cancer'. New York, Sept 15, 1997, p 26.

22 Post ME: Curb bias agrinst mulani-gene carriers. Newsday, Aug 27, 1997, Sect A, p 43.

23 Schiller G. doc-tavish@bigfoot.con Must Read! (visuted Feb 9, 1998), 34ea823.11136336 @news.pboenix.net.

24 Lerhman S: Jewrish leaders fenr gene based antisemitism. Biotechnolosy Newswatch, Oct 6 , 1997, p 1, col 2.

25 Markel H: Di goldine medina (the golden hand) Historical perspectives of eugen ict and the East European (Ashkenazi) Jewish-American community, 1880-1925. Heaith Matrix 1997;7:4964.

152 Community Genet 1998;1:148-153

Rothenberg/Rutkin

Reproduced with permission of the copyright owner. Further reproduction prohibited without permission. 
26 Doctors launch new jewish cancer teat: Amid fear and confusion, wearch for factu begins, For ward, March 1, 1996, p 5.

27 Waldholz M: Scientific weuths link colon cancer to gene in Ashkenazi Jews. Wall Street Jourad Aug 26, 1997, Soct. B, p 1 .

28 Henig RM: Tricky truths sbout ethnicity and genet ics. Washington Poet, Oct S, 1997, Sect C, pl.

29 Grady D: Finding on breast cancer have only complicated the puzale. New York Times, Apr 30,1996, Sect C, p 10, col 1 .

30 Ritter M: Genetic defect aurpriaingly common in Jewish women. Chicago Tribune, Oct 13, 1996, Sect: Womanews, p 9.
31 Kaback M, Lim-Steele J, Dabbolkar D, Brown D, Levy N, Zeiger K: Tay-Suchs disease-carrier acrecning prenstal diagnotis, and the molectlar era. JAMA 1993;270:2307-2315.

32 Wadman M. 'Group debate' urged for gene studies. Nature 1998;391:314.

33 Seschrist L. Bioethics commisenion grappling with stored tisane resench. Bioworld Today 1997;8:204,

34 Blank BT: To test, or not to test: The question plaquing the Jewish community. Forward, Jun 12, 1998, p 1 .

35 National Bioethics Advisory Commision Genetic Subcommittee, (transcripts) Dec 9, 1997 and Jan 6-7, 1998.
36 Foster MW, Bernaten D, Carter TH: A model agrecment for genetic resench in socially identifiuble poppalations. Am 3 Hum Genet 1998; 63:696-702

37 Reilly PR: Rethinking risks to buman subjects in genetic rekeurch. Am J Hum Genet 1998;63: 682-685

38 Juengat ET: Group identity and human diversity: Keeping bidosy straight from culture. Am J Hum Genet 1998;63:673-677.

39 Nation's first formal dialogue on genetics re search implications for Jewish community sponsored by Hudaseah and Jewish Council for Public Affairs. Hadaseah News, Apr 20, 1998.

40 Genetic diseases \& the Jewish community. Congr Monthly 1998;65(4):3-7. 